\title{
Monetary Policy vs. Foreign Exchange Rate: A Statistical Analysis
}

Tyler T. Yu, (Email: tyu@ggc.usg.edu), Georgia Gwinnett College

Miranda M. Zhang, (Email: zhang_mm@mercer.edu), Mercer University

\begin{abstract}
The purpose of this paper is to examine the economic impact of the Fed's rate cuts on foreign exchange movements. Using secondary data, the paper estimates the lagged effects of the changes in money supply due to the rate cuts on the foreign exchange rates between the US dollar and the Japanese Yen (\$/\#), British Pounds (\$/f), and the euro (\$/€), respectively. Since the impact of monetary policy tends to have a time lag, as suggested by Hall and Taylor, the study segments the measurements in six months intervals (6 months form the cut, 12 months from the cut, 18 months from the cut and 24 months from the cut). The relationship between the changes in money supply and potential impact on foreign exchange rate movements will be investigated using the Pearson Product-Moment Correlation coefficients (PPMCC) as well as Spearman's Rank Correlation coefficients (SRCC, the nonparametric alternative to the PPMCC). Then, a hypothesis test will be conducted to determine whether the correlation between the Federal Reserve's stimulating monetary policy and foreign exchange rate movements is significant.
\end{abstract}

\section{INTRODUCTION}

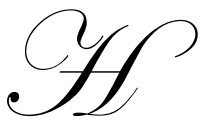

all and Taylor (1997) pointed out that there would be a lag for monetary policy to affect real GDP and prices. It normally takes months for businesses to plan and implement their new investment projects. It also takes time for the American and foreign consumers to take advantage of relatively cheaper price due to changes in exchanges rates caused by increase or decrease in money supply. In terms of consumption, since monetary policy operates though changes in interest rates, it is reasonable to postulate that consumers will need time to adjust their consumption pattern to respond to the change in interest rate, for example, to purchase a new car or furniture. "Monetary policy affects real GDP and prices with a lag. ...... Although there are many uncertainties about the lag in the effect of monetary policy, the peak effect on GDP probably occurs between one and two years after the expansion (1997, p413).”

In 2001, in the midst of the economic recession and later, in response to the 9/11 terrorist attacks, the Federal Reserve lowered the federal fund rate and/or the federal discount rate 11 times. The economic question remains, however, what is the impact of the Federal Reserve's stimulative monetary policy on the value of the dollar relative to the Japanese yen, the British pound, and the Euro.

Carlstrom and Fuerst (2002), both at Federal Reserve Bank of Cleveland, argue that when adopting the rule of inflation-targeting, central banks may eventually run into the problem of exposing inflation to potentially destabilizing shocks. They suggest that central banks should consider a price-level targeting as their rule, which looks at the historic price level. The two researchers also state, in a 2005 research article, that there are two different approaches in disentangling the impacts of oil prices and funds rate movements on economic recession: empirical modeling and theoretical modeling. Although both can be used to measure counterfactually the effects of the Federal Funds rate changes in the wake of oil price shock on output, the authors argue, the empirical approach does not handle expectations very well (2005).

Saeki and Skull (2002) conducted a study examining the monetary policy of the United States. In the study, the authors made two hypotheses and tested both of them: first, a president suffering low popular approval rating is 
likely to influence the Federal Reserve to stimulate the economy and therefore gain popularity. That is, when presidential approval rating is low, the Fed Funds Rate tends to be low. The relationship is weaker for Republican than for Democratic presidents. Second, the Federal Reserve is likely to be responsible for presidential election results. The Federal Funds Rate is likely to be low in reelection years in order to stimulate the economy and boost the incumbent president's popularity. This relationship again is weaker for Republican than for Democratic presidents. Using regression analysis, the empirical results of the study show, among other things, that restrictive monetary policy was a contributing factor during 1954 to 1990, which indicated a lack of the Federal Reserve's concern about employment. In the meantime, the inflation rate is highly and positively related with the Federal Funds Rate, suggesting the Federal Reserve's strong aversion against inflation. Along the partisan line, the study shows that the Federal Funds rate is lower under Democratic presidents, suggesting the Fed's pursue of expansionary monetary policy.

Arokiasamy, Mathur and Sharma conducted a study to examine the effects of anticipated and unanticipated components of U.S. money supply announcements on exchange rates for each day of the week for eight industrialized countries (2000). The authors conclude that the money supply is anticipated prior to the announcement and much of this reaction is fairly evenly spread over the week before the announcement. The reaction to the so-called unanticipated money supply announcements is not totally unanticipated but somehow known prior to the day (Thursday) when the announcement is actually made. According to the study, three explanations shed light on the reaction to unanticipated money supply announcements. First, information is not available to all sectors of the market; second, even if the unanticipated money supply announcement is known, there still exists the question of the reliability of the information; and third, the reactions vary due to heterogeneity in the expectation formulation process.

Joyce and Kamas analyzed the exchange rate determination in three Latin American countries: Argentina, Colombia and Mexico (2003). Using cointegration analysis, the authors examined both real exchange rate and nominal exchange rate. The empirical findings of the paper suggest that the real exchange rate has an equilibrium relationship with real variables - the terms of trade, capital flows, productivity, and government share of GDP; nominal exchange rate accounts for most of the variation in the real exchange rates of the three countries. These variations are affected by central bank intervention, and money supply.

The purpose of this paper is to examine the economic impact of the Fed's rate cuts on foreign exchange movements. Using secondary data, the paper estimates the lagged effects of the changes in money supply due to the

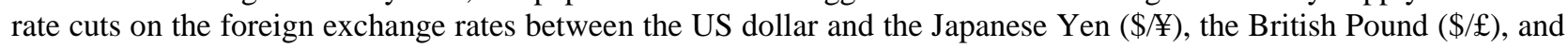
the euro $(\$ / €)$, respectively. Since the impact of monetary policy tends to have a time lag, as suggested by Hall and Taylor, the study segments the measurements in six months intervals (6 months form the cut, 12 months from the cut, 18 months from the cut and 24 months from the cut). The relationship between the changes in money supply and potential impact on foreign exchange rate movements will be investigated using the Pearson Product-Moment Correlation coefficients (PPMCC) as well as Spearman's Rank Correlation coefficients (SRCC, the nonparametric alternative to the PPMCC). Then, a hypothesis test will be conducted to determine whether the correlation between the Federal Reserve's stimulating monetary policy and foreign exchange rate movements is significant.

\section{DESCRIPTIVE MEASURES OF CORRELATION}

The data on the Federal Reserve's rate cuts and the movements of the value of the U.S. dollar against the Japanese yen, the British pound, and the Euro were collected for the period from January 2001 to December 2003 from the Federal Reserve and the Wall Street Journal. The relationship between the rate cuts and its lagged effects on the value of the U.S. dollar was investigated using the Pearson Product-Moment Correlation coefficients as well as Spearman's Rank Correlation coefficients. The Pearson product moment correlation coefficient, Rxy, is defined as follows:

$$
\mathrm{Rxy}=\mathrm{Sxy} /(\mathrm{Sx} \mathrm{Sy}) \text { or Rxy }=\frac{[\Sigma \mathrm{XiYi}-(\Sigma \mathrm{Xi} \Sigma \mathrm{Yi}) / \mathrm{n}]}{\left[\left(\Sigma \mathrm{Xi}^{2}-(\Sigma \mathrm{Xi})^{2}\right) / \mathrm{n} \Sigma \mathrm{Yi}^{2}-(\Sigma \mathrm{Yi})^{2} / \mathrm{n}\right]}
$$

Where, 
Sxy = sample covariance

$\mathrm{Sx}=$ sample standard deviation of $\mathrm{x}$

Sy $=$ sample standard deviation of $\mathrm{y}$

$\mathrm{Xi}=$ the ith observation of $\mathrm{x}$

$\mathrm{Yi}=$ the ith observation of $\mathrm{y}$

The Pearson Product-Moment Correlation method requires that population has a normal distribution. Although there is no reason to believe that the population does not have normal distribution, we want to make certain about the result by applying the Spearman rank-correlation method, the nonparametric alternative to the Pearson Product-Moment Correlation method (Anderson, Sweeney, and Williams, 1999). The Spearman rank-correlation coefficient, Rxy, is as follows:

$\mathrm{Rxy}=1-\left(6 \Sigma \mathrm{di}^{2}\right) / \mathrm{n}\left(\mathrm{n}^{2}-1\right)$

Where,

$\mathrm{n}=$ the number of items or individuals being ranked

$\mathrm{Xi}=$ the number of item $\mathrm{i}$ with respect to one variable

$\mathrm{Yi}=$ the rank of item $\mathrm{i}$ with respect to a second variable

$\mathrm{di}=\mathrm{Xi}-\mathrm{Yi}$

\section{HYPOTHESIS TEST}

The hypotheses can be formulated as follows:

Ho: $\mathrm{Ps}=0$

Ha: $P s \neq 0$

The null hypothesis, Ho, states that there is no (rank) correlation $(\mathrm{Ps}=0)$ between the money supply and the various exchange rates, whereas the alternative hypothesis, Ha, says that there is a rank correlation between the two, $(\mathrm{Ps} \neq 0)$. Under the hypothesis of no rank correlation $(\mathrm{Ps}=0)$, the rankings are independent, and the sampling distribution of Ps is as follows

Urxy $=0$

$\operatorname{Trxy}=\sqrt{ } \square \square 1 / \mathrm{n}-1$

Where: $\mathrm{n} \geq 10$, for normal distribution.

Using SPSS, these two methods were performed on the data: foreign exchange rates and money supply level two (M2). The results were reported in Tables 1,2 and 3.

The dollar yen exchange rate movement appears to be consistent with the lagged effect hypothesis. From Table 1, we can see that the current and 6-month impact of changing money supply in the U.S. on the $\$ \neq$ rate are positive, i.e., as money supply increases in the U.S., the value of the dollar in terms of yen also increases, which is inconsistent with the exchange rate theory. Secondly, the correlation coefficients are statistically insignificant. The 12 to 24 months lags, however, are all negative, meaning, as the money supply in the U.S. increases, the value of the dollar measured against the yen decreases. For example, in December 2001, \$1 was equal to $¥ 126.23$. Two years later in December 2003, \$1 was equal to $¥ 108.23$. The correlation coefficients are mostly statistically significant for PPMCC and SRCC, respectively. 
Table 1

The Results Of The Pearson Product-Moment Correlation Coefficient (PPMCC) And Spearman Rank-Correlation Coefficient (SRCC): M2 vs. \$/¥

\begin{tabular}{|l|c|c|c|c|}
\hline & PPMCC & $\begin{array}{c}\text { Is the Sign as } \\
\text { expected }\end{array}$ & SRCC & $\begin{array}{c}\text { Is the Sign as } \\
\text { expected }\end{array}$ \\
\hline M2 vs. \$/ No Lag & 0.384 & No & 0.291 & No \\
\hline M2 vs. \$/¥ 6 Month Lag & 0.346 & No & 0.509 & No \\
\hline M2 vs. \$/¥ 12 Month Lag & $-0.642^{*}$ & Yes & $-0.709^{*}$ & Yes \\
\hline M2 vs. \$/¥ 18 Month Lag & -0.567 & Yes & $-0.743^{* *}$ & Yes \\
\hline M2 vs. \$/¥ 24 Month Lag & $-0.666^{*}$ & Yes & $-0.738^{* *}$ & Yes \\
\hline
\end{tabular}

Correlation is significant at the 0.05 level. Correlation is significant at the 0.01 level.

Table 2

The Results Of The Pearson Product-Moment Correlation Coefficient And Spearman Rank-Correlation Coefficient

M2 vs. \$/£

\begin{tabular}{|l|c|c|c|c|}
\hline & PPMCC & $\begin{array}{c}\text { Is the Sign as } \\
\text { expected }\end{array}$ & SRCC & $\begin{array}{c}\text { Is the Sign as } \\
\text { expected }\end{array}$ \\
\hline M2 vs. \$/£ No Lag & 0.060 & No & -0.109 & Yes \\
\hline M2 vs. \$/ 6 Month Lag & $-0.676^{*}$ & Yes & -0.600 & Yes \\
\hline M2 vs. \$1 12 Month Lag & $-0.887^{* *}$ & Yes & $-0.891^{* *}$ & Yes \\
\hline M2 vs. \$ $£ 18$ Month Lag & $-0.782^{* *}$ & Yes & $-0.818^{* *}$ & Yes \\
\hline M2 vs. \$/ $\$$ 24 Month Lag & -0.465 & Yes & -0.345 & Yes \\
\hline
\end{tabular}

Correlation is significant at the 0.05 level. Correlation is significant at the 0.01 level.

The relationship between U.S. dollar and the British pound also seems to be consistent with the lagged effect hypothesis. As shown in Table 2, the current effect of increasing money supply is insignificant at $95 \%$ and $99 \%$ confidence levels, respectively. Starting from the 6-month lag, the sign and correlation coefficients are as expected: negative signs indicate that as money supply increases, ceteris paribus, the value of the dollar in terms of the British pound decreases. For example, in December 2001, \$1 was equal to $£ 0.696136$. Two years later in December $2003, \$ 1$ was equal to $£ 0.573230$. Also, the correlation coefficients for the 12-month and 18-month periods are both statistically significant for the two selected measures PPMCC and SRCC, respectively. The lagged effect appears to fade away when it gets to the 24-month period.

As shown in Table 3, the correlation coefficients generated by both methods are consistent with economic theory, as indicated by the signs. As the money supply in the U.S. increases, the value of the dollar measured relative to the euro decreases. For example, in December 2001, \$1 was equal to $€ 1.123090$. Two years later in December 2003, $\$ 1$ was equal to $€ 0.822098$. The PPMCC from the 6-month lag and the SRCC from the 12-month lag are statistically significant at the $95 \%$ or $99 \%$ confidence levels, respectively.

Table 3

The Results Of The Pearson Product-Moment Correlation Coefficient And Spearman Rank-Correlation Coefficient

M2 vs. \$/€

\begin{tabular}{|l|c|c|c|c|}
\hline & PPMCC & $\begin{array}{c}\text { Is the Sign as } \\
\text { expected }\end{array}$ & SRCC & $\begin{array}{c}\text { Is the Sign as } \\
\text { expected }\end{array}$ \\
\hline M2 vs. \$/€ No Lag & 0.246 & No & 0.227 & No \\
\hline M2 vs. \$/€ 6 Month Lag & $-0.646^{*}$ & Yes & 0.600 & No \\
\hline M2 vs. \$/€ 12 Month Lag & $-0.855^{* *}$ & Yes & $-0.864^{* *}$ & Yes \\
\hline M2 vs. \$/€ 18 Month Lag & $-0.940^{* *}$ & Yes & $-0.927^{* *}$ & Yes \\
\hline M2 vs. \$/€ 24 Month Lag & $-0.865^{* *}$ & Yes & $-0.627^{*}$ & Yes \\
\hline
\end{tabular}

Correlation is significant at the 0.05 level. Correlation is significant at the 0.01 level. 


\section{CONCLUSIONS}

Under the current flexible exchange rate system, according to the asset markets approach to the exchange rate determination, the exchange rate is a price that equalizes the supply and the demand of stocks of financial assets (Kreinin, 1991). That is, it is determined by the degree of desire to hold stocks of assets denominated in a particular currency and the amount of that currency available in supply. As pointed by Kreinin, "of all the assets, particular importance is attached to money. Thus, relative rates of money growth between two countries are a prime determinant of exchange rate between the two respective currencies in the short run (Kreinin, 1991, pg. 160)." More specifically, the exchange rate between two currencies must reflect their respective purchasing power, which is determined by the relative price levels in the two countries. The price levels are at least partially determined by the money supply (McKinnon, Dornbusch, and Williamson, 1988).

The empirical results of this study show that:

- $\quad$ There appears to be correlation between money supply and value of the U.S. dollar measured in terms of the Japanese yen, the British pound, and the euro. As the money supply in the U.S. increases, the value of the dollar relative to the three currencies decreases.

- $\quad$ The effects of money supply on the value of the dollar appear to have a time lag. The lags for all three exchange rates are consistent with the hypothesis formulated by Hall and Taylor. That is, it takes at least six months (in the case of Japanese yen 12 months) after the Fed increases money supply for us to see the value of the dollar to depreciate.

- The hypothesis tests indicate that there is a significant negative correlation between the money supply (measured in M2) and the value of the dollar measured against the three currencies selected for this study. The levels of significance range from $95 \%$ to $99 \%$, respectively.

\section{REFERENCES}

1. Arokiasamy, Frank, Mathur, Ike, and Subhash, C. Sharma, Effects of U.S. Money Announcements on the Daily Exchange Rates of Industrialized Countries, Applied Economics, Vol. 32, Issue 5, pg 593, 2000.

2. Carlstrom, Charles T. and Timothy S. Fuerst, Monetary Policy Rules and Stability: Inflation Targeting versus Price-Level Targeting, Economic Commentary, Federal Reserve Bank of Cleveland, February 15, 2002.

3. Hall, Robert E. and John B. Taylor, Macroeconomics, $5^{\text {th }}$ edition, Norton, 1997.

4. Joyce, Joseph P. and Linda Kamas, Real and Nominal Determinants of Real Exchange Rates in Latin America: short-run Dynamics and Long-run Equilibrium, Journal of Development Studies, Vol. 39, Issue 6, pg 155, August 2003.

5. $\quad$ Kreinin, Mordechai E, International Economics, sixth edition, HBJ, 1991.

6. McKinnon, R., Dornbusch, R., and J. Williamson, the Journal of Economic perspective, Winter 1988.

7. Saeki, Manabu and Steven A. Skull, Explaining Federal Reserve Monetary Policy, Review of Policy Research, Vol. 19, Issue 2, Summer 2002, pp128. 
NOTES 